\title{
Research on College ESP Teaching for Chinese P.E Majors
}

\section{MA}

Foreign Language School of East China Jiaotong University, Nanchang, Jiangxi, China

T. J. HE

Physical School of East China Jiaotong University, Nanchang, Jiangxi, China

\begin{abstract}
With increasing international communication in sports field, it is helpful for P.E majors today to be equipped with equivalent level of English capability. And nowadays, the main part of college English teaching has gradually transferred from EGP to ESP. On the analysis of current English teaching situation of P.E majors, this paper discusses relevant problems standing during the practice, such as the uneven English level of students, the lack of ESP teaching textbooks and the lack of capable teachers. At the same time, it proposes several possible solutions.
\end{abstract}

KEYWORD: P.E majors; English teaching; ESP; relevant problems; solutions

\section{INTRODUCTION}

The full name of ESP is English for Special Purpose which was proposed by Halliday in 1960s (Halliday, 1964). It mainly refers to the specific English which is closely connected with certain subject or career. And ESP teaching is based on the learners' special needs and training objectives. Nowadays, ESP teaching in many western countries has its established system including business English, legal English and so on. Meanwhile, in many Asia countries and areas, ESP teaching has became the mainstream of college English teaching. Since 1980s, Chinese college English teaching is mainly for the general purpose, which is called EGP. Due to the increasing frequent foreign exchanges in the field of culture, politics, economy and sports after China's accession to WTO, every walks of life in China has growing strong demand for talents who have both professional and proficient language skills. Therefore, ESP teaching in China is growing rapidly. According to Profession R.Q.Liu, ESP teaching will be the mainstream of English education in 21 century (Liu, 1996). Profession J.G.Cai also believes that with expansion of China's international exchanges and the improving English level of Chinese university students, college English teaching will mainly develop into ESP teaching (Cai, 2004).

\section{CURRENT SITUATION OF ENGLIGH TEACHING FOR P.E MAJORS}

Because of the admission requirements for sports majors in college entrance examination are relatively lower, coupled with its professional characteristics of P.E majors, their English foundation are weak and level are uneven, which makes the English teaching for P.E majors facing great difficulties. The students with high English level show no enthusiasm in class while those with low English level find difficulty in joining the class activities because they cannot even understand the simple and basic class language. All these have caused the great embarrassment both for teachers and students. In addition, the college English teaching materials of P.E students are not usually closely relevant to their major, to them English teaching is still for the general purpose. Therefore, most of the P.E majors think it is of no use for them to learn college English. Furthermore, in considering for those students with low English level, teachers usually just teach rather basic knowledge by adopting inflexible and dull teaching methods. This monotonous teaching makes the lively P.E students quickly lose their interest and enthusiasm in leaning.

\section{NEED-BASED ANALYSIS OF P.E MAJORS IN ESP TEACHING}

Need-based analysis is proposed by Munby in his research of curriculum design of ESP teaching 
(Munby, 1978). He thinks that need analysis is the first priority of ESP teaching. According to Munby, curriculum design should be based on the confirmation of what learners want to learn after analyzing their communicative needs and specific communicative goals. Many Chinese scholars also have done some researches on ESP teaching based on need analysis. Professor D.F. Su thinks that need analysis should be clarified and discussed from two aspects of social and individual demands (Su, 2004). According to another professor B.B. Chen, the awareness of need-based analysis in foreign language teaching should be strengthened and must be applied in every course of foreign language teaching (Chen, 2009). From the above analyses of many scholars, need-based analysis is to analyze the social and industrial requirements for ESP teaching on the macro level; while on the micro level, it refers to the analysis of learners' demands of ESP teaching. Then, what specific needs exist in the ESP teaching of P.E majors?

\subsection{The need from the development of sports and culture foreign exchanges}

Along with the process of globalization, political, economical and cultural exchanges between countries are further strengthened. Among these international exchanges, sports exchange is of great importance. In recent years, Chinese athletes are constantly wining in some traditional advantageous events, and getting some major breakthroughs in some weak sports events. All these achievements contributed significantly to the further sports exchanges between countries because the experience on advantageous events need to be passed on while on the weak ones need to be learned. However, one of the biggest problems in many sports exchanges is the miscommunication due to language. The mainly reason for that is because the English teaching for P.E majors shows no differences with common English teaching for other majors and rarely links with sports professional knowledge, which makes students feel useless to learn. Therefore, it is very urgent to enhance the English teaching of P.E students who are the major force in the international sports exchanges in order to make them be equipped with both professional knowledge and proficient language skills.

\subsection{The need from the college English teaching reform}

In respond to the requirements of new college English curriculum issued by Chinese Ministry of Education, many universities and colleges have carried out the English teaching reform. But the focus of it is mainly about how to teach the student with different English levels, namely adopting graded English teaching as the main direction of the reform. However, the band 1 to 4 college English courses and even the follow-up courses are mostly about teaching simple English language, literature and culture, rarely involve some professional vocabulary and terms, which cannot meet the demand of comprehensive high quality talents in the economic development. Thus adding appropriate professional knowledge in college English teaching will be a feasible idea and an important direction in the next round of its reform.

\subsection{The need from P.E majors' self-development}

Through the survey carried out by the author, P.E students' purposes of learning English are as follows: to get to know the foreign sports culture, to meet communication need, to obtain the certificate of band 4 or 6 English test, to improve professional skills, to find a good job, to meet the demand of future work and so on. And the majority of students' purposes are to enhance the professional skills, to find a good job and to meet the demands of future work. However, after many years of English learning, many P.E majors find difficulties in understanding the professional sports English in some international sports events or in their work practice, causing them losing some opportunities of self-development. Therefore, in the environment of needing the talents who have both professional skills and English proficiency, English teaching for P.E majors should help them to optimize their professional knowledge structure, maximally be combined with students' actual needs and cultivate their English communication ability for their future particular field of work.

\section{EXISTING PROBLEMS IN CURRENT ESP TEACHING OF P.E MAJORS}

\subsection{Uneven English levels of P.E students}

Most of P.E students was specializing their energy and time in sport training since high school, along with the relatively low requirements of college entrance examination, their English foundation is rather weak. After entering university, P.E students' spare time was consumed by the training practices, so they did not attach enough importance to English learning as well as enough time. Therefore, a lot of P.E students' English levels are still in the primary stage of English learning, they cannot understand some basic class English expressions let alone use English comprehensively. This situation makes the ESP teaching easily fall into the simple translation teaching method, and ESP teaching even reverts to the old EGP teaching, rather than achieving desired teaching results. At the same, although most of P.E students' English levels are low, there are still some 
students with higher English level. The simple teaching methods and approaches just cannot satisfy them and make them lose interest in learning English let alone cultivate and improve their comprehensive application ability of English. So, the uneven English levels of students make it very hard for teachers to take the needs of different students into consideration during ESP teaching and successfully carry out the teaching process.

\subsection{Lack of practical ESP teaching textbooks}

The current English textbooks for P.E students are mostly simple, and in many cases also used by other majors such as Music and Art. Besides that, the content of textbooks are rarely involve specialized sports knowledge and vocabulary, so it cannot meet the requirements of P.E students' ESP teaching. in many colleges, the choices of ESP teaching textbooks are rather chaotic, some of them are original English textbooks while others are teachers' customized teaching materials. Many problems will arise from that, such as uneven difficulty level of textbooks, the lack of authority and interestingness. Consequently, the lack of suitable and practical teaching textbooks is now becoming a major problem in ESP teaching for P.E students.

\subsection{Lack of teachers with professional sports knowledge}

Linguistic J. Jarvis believes that one important ability of teachers should have in ESP teaching is the ability to analyze the English for specific purposes and situations (Jarvis, 1983). Nowadays, most of the P.E English teachers are English majors who graduated from normal universities. These teachers usually have solid language knowledge, but the common problem of them is the lack of adequate professional sports knowledge, making the hardly meet the requirements as an ESP teacher, such as with profound expertise, accurate expression of professional terms and explanation professional vocabulary. Therefore, the lack of teachers with professional sports knowledge has become one of the main factors affecting and restraining the ESP teaching of P.E students.

\section{SUGGESTIONS OF DEVELOPING ESP TEACHING IN P.E MAJORS}

\subsection{Stabilize and strengthen the teachers' team}

There are many affecting factors in ESP teaching, one of the most important factor is the teaching faculty. According to Z.Z. GU, whether the compilation of textbook, the organization of classroom teaching activities, the implementation of teaching method or the evaluation of teaching effect are all inseparable from the teacher who is the key factor in the ESP teaching (Gu, 2010). Due to the single knowledge structure and lack of professional sports knowledge, most of the college English teachers are unqualified for ESP teaching. At the same time, many English teachers are unwilling to teach the P.E majors because of their poor language foundation. So, the phenomena of changing teachers frequently have occurred, which is not conducive to the relationship between teachers and students. Moreover, most of English teachers lack the knowledge of related ESP teaching theories, which makes their ESP teaching only stays in the early stage. All these circumstances are not conducive to the development of ESP teaching for P.E students. Therefore, P.E English teachers' team must be stabilized. And then, on that basis, strengthen their professional sports knowledge and ESP theoretical knowledge through the department cooperation, professional training and experience exchanges. Thereby, the goal of improving teachers' ability can be finally achieved.

\subsection{Regulate ESP teaching textbooks of P.E students}

The theory of ESP teaching was introduced into China since 1970s. After a long time of development, so far there is still no one set of unified ESP teaching textbooks, including sports ESP teaching textbooks. A considerable number of teachers have reflected the important and common problem in ESP teaching is the lack of proper teaching textbooks. Most of the teaching materials are just selected from professional sports literature, which lack coherence and corresponding relation. By using these materials, it is very hard to improve students' English comprehensive ability. Therefore, the unification of ESP teaching textbooks is rather necessary, and it will also be beneficial to increase the level of ESP teaching level in China.

\subsection{Adopt multiple ESP teaching methods}

The traditional ESP teaching practice is all about explaining the professional terms, in which there is no interaction between teachers and students who can easily be bored. So, its teaching effect is not good, and at the same time there is no sign of student centered concept. In good ESP teaching practice, teachers should take students as the teaching center. according to the teaching contents, teacher help students fulfill the task of language learning and application in a relaxed and pleasant atmosphere by using many communicative teaching methods such as situational dialogues, role-playing and scene simulation, as well as the help of multimedia and other modern teaching means. 


\section{CONCLUSION}

ESP teaching is the product of social development and global integration, and it certainly will be the mainstream of English teaching in the future. Because of the special nature of physical education, P.E majors' ESP teaching is particularly important. Although it is greatly challenged by the students' uneven English level, teachers' lack of professional knowledge and many other factors, it definitely can be improved and achieved through some effective strategies.

\section{REFERENCES}

[1] Arani, J. 2005. Teaching writing and reading English in ESP through a web-based communicative medium. Weblog, ESP world 3(11):4.
[2] Cai, J.G. 2004. ESP and new direction of college English teaching development. Foreign Language World 100(2): 22-28.

[3] Chen, B.B. 2009. Literature review on foreign research of need-based analysis. Foreign Language Teaching and Research 49(2): 125-130.

[4] Gu, Z.Z. 2010. Analysis of current ESP teaching and coping strategies. Computer-Assisted Foreign Language Education 33(5): 25-29.

[5] Halliday, M.A.K, McIntosh, A. \& Strevens, P. 1964. The Linguistic Sciences and Language Teaching. London: Longman.

[6] Hutchinson, I. \& Waters, A. 1993. English for Specific Purposes: A Learning-centered Approach. Cambridge: Cambridge University Press.

[7] Jarvis, J. 1983. Two core skills for ESP teacher. The ESP Journal 2(1).

[8] Liu, R.Q. 1996. Notes on the report from "English 2000". Foreign Language Teaching and Research 106(2):1-8.

[9] Munby, J. 1978. Communicative Syllabus Design. Cambridge: Cambridge University Press.

[10] Su, D.F. 2004. FLT in China: Problems and Suggested Solutions. Shanghai: Shanghai Foreign Language Education Press. 